https://jurnal.univpgripalembang.ac.id/index.php/luminous

\title{
EFEKTIVITAS PEMBELAJARAN DAN RESPON SISWA TERHADAP PENGGUNAAN BUKU AJAR FISIKA TERMODINAMIKA BERBASIS KONTEKSTUAL
}

\author{
Yaspin Yolanda ${ }^{1 *}$, Muhamad Imaduddin ${ }^{2}$, \\ ${ }^{1}$ Program Studi Pendidikan Fisika STKIP PGRI Lubuklinggau \\ Alamat Jalan Mayor Toha Kel. Air Kuti Telp. (0733) 452432, Kota Lubuklinggau, 31626 \\ Yaspinyolandayy22@gmail.com \\ ${ }^{2}$ Program Studi Program Studi Tadris Ilmu Pengetahuan Alam (IPA), Institut Agama Islam Negeri Kudus \\ Jl. Gondangmanis No.51, Ngembal Rejo, Kec. Bae, Kabupaten Kudus, Jawa Tengah 59322 \\ imad@iainkudus.ac.id
}

Received: 2401 2021. Accepted: 0902 2021. Published: 15022021

\begin{abstract}
Abstrak
Berdasarkan hasil observasi dan wawancara peneliti di MAN 1 Model Lubuklinggau yang menunjukkan bahwa mata pelajaran termodinamika masih belum bisa mengukur kemampuan kognitif siswa dalam mengerjakan soal-soal yang diberikan, dan 72,5 persen siswa mendapatkan nilai kurang memuaskan yakni mendapat nilai dibawah 60 . Bedasarkan permasalahan diatas, pengembangan buku ajar ini bertujuan untuk mengetahui efek potensial buku ajar termodinamika yang sesuai dengan kebutuhan siswa pendidikan fisika STKIP PGRI Kota Lubuklinggau. Metode research and development yang digunakan menurut Borg dan Gall, karena sangat cocok untuk mengembangkan dan memvalidasi produk pendidikan. Adapun Tahapannya terdiri dari 10 langkah yakni (1) pengumpulan data, (2) perencanaan (3) pengembangan produk awal, (4) uji coba terbatas, (5) Revisi pertama, (6) uji coba kelas kecil, (7) Revisi kedua, (8) Uji kelas luas, (9) revisi akhir, dan (10) diseminasi produk. Berdasarkan hasil penelitian dengan menggunakan buku ajar mata kuliah termodinamika berbasis kontekstual pada semester ganjil serta sampel diteliti pada uji coba one to one, uji coba small group dan uji field test menunjukkan buku ajar termodinamika ini berbasis kontekstual adalah valid, praktis dan efektif dengan kategori baik. Hasil penilaian validator terhadap kualitas buku ajar fisika berbasis kontekstual dengan presentase $88,73 \%$. Ketuntasan efektivitas pembelajaran secara klasikal sebesar $85,7 \%$ dan sangat efektif digunakan meningkatkan hasil belajar siswa dan respon siswa sangat baik.
\end{abstract}

Kata kunci : Termodinamika, Efektivitas, Respon Siswa, Kontekstual.

\section{PENDAHULUAN}

Penelitian ini diambil berdasarkan hasil observasi dan wawancara peneliti di MAN 1 Model Lubuklinggau yang menunjukkan bahwa mata pelajaran termodinamika belum bisa mengukur kemampuan kognitif siswa dalam mengerjakan soal-soal yang diberikan, dan 72,5 persen siswa mendapatkan nilai kurang memuaskan yakni mendapat nilai dibawah 60. Apalagi mata pelajaran ini menjadi mata pelajaran dengan tingkat kesulitan bagi siswa sehingga fisika pada 
pokok bahasan termodinamika masih dipandang sebagai pembelajaran yang menakutkan, banyak rumusan yang harus dihapal, siswa belum menemukan makna, kebermanfaatan ketika diajarkan oleh guru, siswa kesulitan dalam hitung, kesulitan memahami konsep fisika yang diajarkan, masih banyak yang mengalami miskonsepsi dalam belajar fisika khususnya termodinamika. Selanjutnya siswa merasa malas untuk membaca buku teks fisika yang digunakan karena banyak rumusan, sejalan dengan pendapat Yolanda, Y. (2018) mengatakan bahwa fisika tidak menarik karena pelajaran yang menakutkan.

Seorang pengajar harus mampu membuat desain buku ajar sesuai dengan analisa kebutuhan siswa dan harus mampu menjawab permasalahan yang ada, Yolanda, Y. (2019). Seorang guru harus mampu membuat buku ajar berbasis kontekstual, praktis dan efektif yang bertujuan meningkatkan hasil belajar siswa, menarik minat siswa membaca, Trianto. (2013). Selanjutnya penggunaan buku ajar bisa meningkatkan hasil belajar siswa, Nasution. (2012). Berdasarkan observasi, siswa kesulitan hitung, dan masih banyak yang mengalami miskonsepsi termodinamika, penggunaan laboratorium dalam pembelajaran fisika tidak pernah dilaksanakan. Selanjutnya siswa merasa malas untuk membaca buku teks fisika yang banyak rumusan. Selanjutnya temuan dilapangan selain minimnya referensi mata pelajaran ini yang menjadi sumber masalah selanjutnya adalah kesulitan dan miskonsepsi siswa dalam memahami termodinamika.

Banyaknya pendidik yang masih menggunakan buku ajar konvensional, yaitu buku ajar tinggal pakai dan tinggal beli tanpa ada upaya menyusun sendiri dan buku ajar yang digunakan tidak kontekstual, tidak menarik, monoton dan tidak sesuai dengan kebutuhan siswa, Yanti, Ana Isqa Riski. (2013). Selanjutnya Yaspin, Y. (2020) dan Johnson, Elaine B. (2009) dan Hosnan, M. (2016) mengatakan bahwa pembelajaran kontekstual adalah pembelajaran yang mampu membangun kebermaknaan (construktivism), Fayakun, M dan Joko, P., (2015) mengatakan pembelajaran ini indetik dengan penemuan (inquiry), belajar bersama (learning community), pembelajaran berdasarkan konteksnya (modelling), penilaiannya autentik dan mampu mengukur tingkat kemampuan siswa (authentic assesment), Memberikan kesempatan kepada siswa untuk bertanya (questioning), dan membimbing siswa dalam mereview kembali materi yang telah diajarkan (reflection).

Yuliyanti, T.E \& A. Rusilowati. (2014) mengatakan bahwa buku ajar merupakan komponen pendidikan yang sangat penting dalam proses pembelajaran. Tersedianya buku ajar yang berkualitas akan mendukung keberhasilan proses pembelajaran. Namun buku-buku ajar yang ada selama ini lebih menekankan kepada dimensi konten daripada dimensi proses dan konteks sebagaimana dituntut oleh Programme for International Student Assesment (PISA). Kondisi tersebut diduga menyebabkan rendahnya tingkat literasi sains anak Indonesia. Menurut Baroh, Chasniatul. (2010) mengatakan bahwa dalam pembelajaran di kelas seorang guru juga sebaiknya memiliki buku ajar yang tepat. Buku ajar juga menjadi salah satu faktor pendukung terwujudnya pembelajaran yang efisien. Murtiani. (2012) dan Fayakun, M dan Joko, P., (2015) mengatakan baha buku ajar yang sinergis dan berjalan sesuai dengan model pembelajaran yang akan dilakukan diharapkan mampu meningkatkan hasil belajar. Yasa, G. A. A. S., (2012) mengatakan bahwa sumber belajar yang diorganisir melalui suatu rancangan yang dimafaatkan sebagai sumber ajar dapat bermanfaat bagi seorang guru mapun peserta didiknya. Buku ajar yang sesuai dengan model pembelajaran menjadi hal penting agar pembelajaran dapat bermanfaat dan mencapai tujuannya.

Menurut Utomo, L. A., \& Muslimin. (2015). Penggunaan buku sebagai buku ajar yang saat ini masih menjadi pegangan seorang guru dalam mengajar masih kurang sesuai dengan metode kontekstual. Sujanem, R., (2012) mengatakan bahwa buku yang biasa digunakan oleh guru adalah buku dari penerbit yang mana isi dalam buku tersebut berupa materi dan penugasan dalam bentuk soal. Buku yang digunakan guru dari 
penerbit masih belum selaras dengan model pendekatan kontekstual. Disamping itu, faktor guru dan metode pembelajaran juga berpengaruh pada minat siswa untuk mempelajari fisika. Selama ini guru menyampaikan materi pelajaran dengan metode ceramah kemudian dilengkapi dengan rumus-rumus dan perhitungan secara garis besarnya saja, sehingga kegiatan belajar berlangsung satu arah karena guru masih mendominasi dalam pembelajaran.

Serway, Raymond A. dan Jhon W. Jewett. (2009) mengatakan bahwa materi termodinamika merupakan materi aktual yang bisa diterapkan dengan konsep ilmiah sehingga siswa dapat berpikir seperti seorang ilmuwan dalam memecahkan suatu masalah. Zhang, Y. (2001) mengatakan bahwa termodinamika mempelajari konsep perubahan energi, panas, kerja, entropi dan kespontanan proses. Aplikasi penerapan hukum termodinamika tentang konsep pertukaran energi dalam bentuk kalor dan kerja, sistem pembatas dan lingkungan sering kita jumpai dalam kehidupan sehari-hari yakni prinsip kerja kulkas, prinsip kerja AC, peristiwa meniup kopi panas, prinsip kerja mesin mobil, dan pembangkit listrik. Sehingga materi ini sangat penting untuk diajarkan secara optimal, agar dapat menghasilkan konsep yang benar, Imaduddin, M., dkk. (2020) dan Sujanem, R., (2012). Dari uraian diatas maka perlu dikembangkan buku ajar fisika yang berbasis kontekstual dengan materi termodinamika. Pada buku ajar fisika berbasis kontekstual ini siswa diajak untuk lebih aktif dalam proses pembelajaran, karena dalam buku ajar fisika berbasis kontekstual ini berisikan lima komponen kontekstual yang dapat meningkatkan hasil belajar siswa.

Yuliyanti, T.E dan A. Rusilowati. (2014) dan Chaedar. A. (2009) mengatakan bahwa pembelajaran dikatakan efektif apabila memenuhi persyaratan utama keefektifan pengajaran yaitu (a). Antusias siswa dalam belajar sangat tinggi; (b). Setiawan, Denny, dkk. (2017) juga mengatakan bahwa rata-rata siswa aktif melaksanakan tugas yang diberikan guru; (c). memahami materi yang diajarkan dan tahu bagaimana penerapan materi tersebut dalam kehidupan sehari-hari; (d). pembelajaran berpusat kepada siswa sehingga terciptanya pembelajaran yang aktif, (d). Efektivitas hasil belajar setelah menggunakan buku ajar dalam penelitian ini dilihat dalam terlaksananya semua tugas pokok, Emzir. (2011). Selanjutnya tercapainya tujuan, ketepatan waktu, adanya partisipasi aktif dari peserta didik sehingga efektivitas hasil belajar mencapai ketuntasan $\mathrm{KKM} \geq 70$ dengan persentase ketuntasan $>80 \%$ dan respon siswa terhadap penggunaan model pembelajaran kontekstual baik, Baroh, Chasniatul. (2010) dan Setiawan, Denny, dkk. (2017).

Respon merupakan gerakan-gerakan yang terkoordinasi oleh persepsi seseorang terhadap peristiwa luar dalam lingkungan sekitar, Tegeh, I., dkk. (2014). Selanjutnya Zulhaini, dkk. (2016) menjabarkan bahwa untuk mengetahui respon seseorang terhadap sesuatu dapat melalui angket, karena angket pada umumnya meminta keterangan tentang fakta yang diketahui oleh responden mengenai pendapat atau sikapnya yang akan dideskripsikan dalam indikator meliputi (a). Respon siswa terhadap proses pembelajaran dengan model pembelajaran. Dan (b). Sikap siswa terhadap fisika setelah mengikuti pembelajaran fisika dengan menggunakan model pembelajaran, sejalan dengan pendapat Chaedar. A. (2009) dan Sujanem, R., (2012).

Berdasarkan pejelasan yang telah diuraikan dan beberapa permasalahan di atas, maka tujuan penelitiannya adalah:

1. Untuk mengetahui efektivitas hasil belajar siswa kelas XI di MAN 1 Model Lubuklinggau Tahun Pelajaran 2019/2020 setelah menggunakan buku ajar fisika berbasis kontekstual materi termodinamika.

2. Untuk mengetahui respon siswa terhadap pembelajaran menggunakan pendekatan kontekstual materi termodinamika siswa kelas XI di MAN 1 Model Lubuklinggau Tahun Pelajaran 2019/2020.

\section{METODE}

Sugiyono. (2012) mengatakan bahwa metode penelitian eksperimen sangat cocok untuk 
mengukur efektivitas hasil belajar menggunakan analisa uji hiptesis. hal ini sejalan dengan pendapat Tomlinson, Brian. (2011) dan Gall, Joyce P. Gall \& Walter R. Borg (2010) mengatakan bahwa model pengembangan Borg and Gall karena penggunaan buku ajar hasil pengembangan ini menggunakan model pengembangannya sangat cocok untuk membuat produk ajar. Sampel penelitian yang dilaksanakan dari Januari s.d April 2019 adalah siswa kelas XI MAN 1 Model Lubuklinggau. Observer melibatkan tim peneliti. Berdasarkan penelitian terdahulu, buku ajar ini telah dikembangkan dan divalidasi oleh Validator materi termodinamika adalah Ida Kurnia, M.Pd. selaku validator materi. Bapak Risda NIla, M.Pd. selaku validator struktur kurikulum dan kekontekstualan. Selanjutnya Bapak Dodik Mulyono, M.Pd selaku validator tata letak dan grafis. Selanjutnya Setiawan, Denny, dkk. (2017) dan Yolanda, Y. (2020) mengatakan bahwa ada sepuluh langkah pengembangan seperti tabel 1 .

Tabel 1. Langkah Borg and Gall

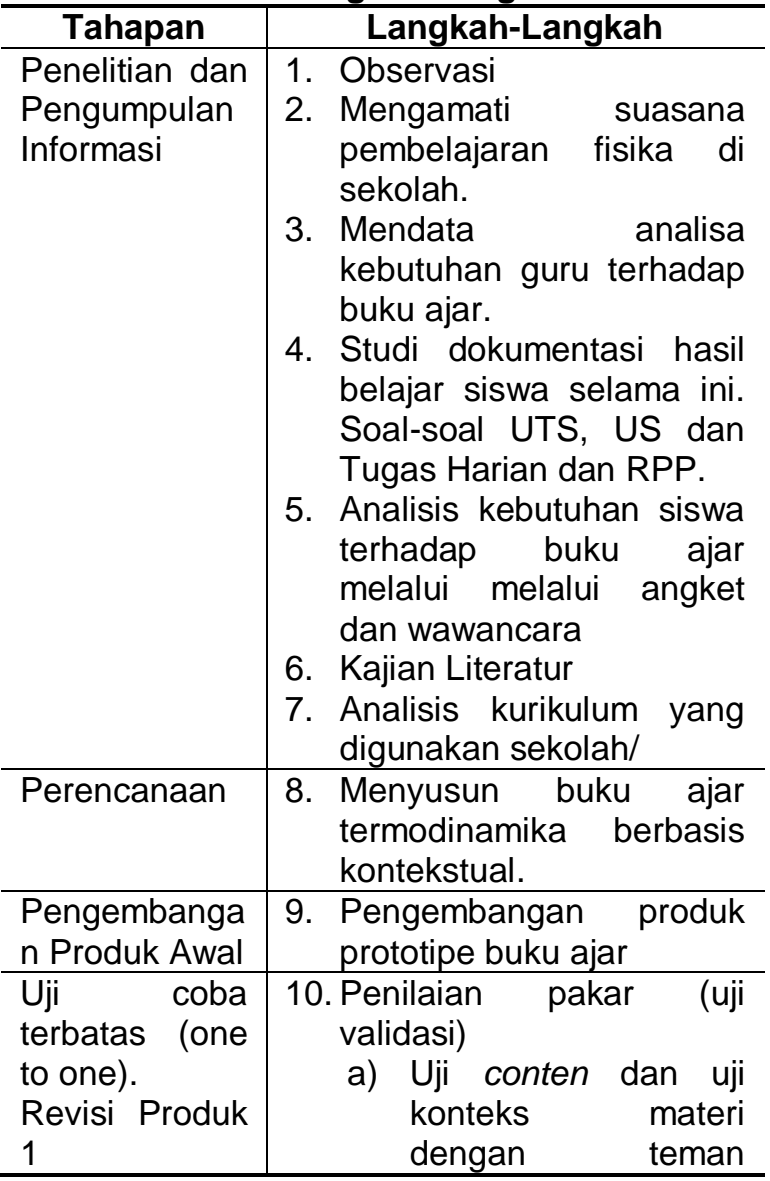

\begin{tabular}{|c|c|}
\hline & $\begin{array}{l}\text { sejawad } \\
\text { b) Uji analisa kurikulum } \\
\text { dan capaian } \\
\text { pembelajaran (uji } \\
\text { kesesuaian) } \\
\text { c) Uji tampilan, desain } \\
\text { grafis buku ajar. }\end{array}$ \\
\hline $\begin{array}{l}\text { Uji lapangan } \\
\text { field test (uji } \\
\text { coba luas) } \\
\text { Revisi produk } \\
2\end{array}$ & $\begin{array}{l}\text { 11. Penilaian pakar (uji } \\
\text { validasi) } \\
\text { a) Uji conten dan uji konteks } \\
\text { materi dengan teman } \\
\text { sejawad } \\
\text { b) Uji analisa kurikulum dan } \\
\text { capaian pembelajaran (uji } \\
\text { kesesuaian) } \\
\text { c) Uji tampilan, desain grafis } \\
\text { buku ajar. }\end{array}$ \\
\hline $\begin{array}{l}\text { Uji lapangan } \\
\text { operasional }\end{array}$ & $\begin{array}{l}\text { 12. Efektivitas penggunaan } \\
\text { buku ajar di Sekolah. }\end{array}$ \\
\hline $\begin{array}{l}\text { Revisi produk } \\
\text { akhir }\end{array}$ & 13. Model akhir buku ajar \\
\hline $\begin{array}{l}\text { Disosialisasik } \\
\text { an dan di } \\
\text { implementasi } \\
\text { dalam } \\
\text { pembelajaran } \\
\end{array}$ & $\begin{array}{l}\text { 14. Disosialisasikan dalam } \\
\text { focus group discussion } \\
\text { dan diimplementasikan } \\
\text { bagi guru fisika dalam } \\
\text { pembelajaran di sekolah. }\end{array}$ \\
\hline
\end{tabular}

Menurut Gay, L.R. dan Geoffrey E. Mills Peter Airasian. (2009) dan Yasa , G. A. A. S., (2012) mengatakan bahwa teknik Pengumpulan data pada penelitian dan pengembangan ini dilakukan dengan teknik angket dan tes hasil belajar, Yolanda, Y. (2019). Selanjutnya Sugiyono. (2012), Murtiani. (2012) dan Zulhaini, dkk. (2016). mengatakan bahwa analisis data ini dilakukan pada tahap pendahuluan, saat pengembangan buku ajar, analisis data pada tahap validasi, evaluasi, dan revisi buku ajar, serta pada tahap implementasi buku ajar seperti pada tabel 2 .

Tabel 2. Instrumen dan Analisa Data

\begin{tabular}{l|l|c}
\hline Jenis Data & Instrumen & Analisis Data \\
\hline $\begin{array}{l}\text { Efektivitas } \\
\text { Belajar }\end{array}$ & $\begin{array}{l}\text { Soal Pretet } \\
\text { dan posttes }\end{array}$ & Analisa deskriptif \\
\hline $\begin{array}{l}\text { Respon } \\
\text { siswa }\end{array}$ & Angket & Analisa deskriptif \\
\hline
\end{tabular}

\section{HASIL DAN PEMBAHASAN}

Hasil

Kelayakan buku ajar fisika berbasis kontekstual secara teoritik melalui tahapan 
evaluasi ahli untuk melihat kevalidan buku ajar yang di validasi oleh para ahli. Evaluasi ahli dilakukan untuk menyempurnakan buku ajar yang dikembangkan dari segi materi, media, dan bahasa. Berdasarkan penilaian dari ketiga orang ahli terhadap buku ajar berbasis kontekstual yang sudah diuraikan di atas menunjukkan penilaian yang sangat baik. Oleh karena itu, buku ajar berbasis kontekstual dapat dikatakan valid dan dapat digunakan untuk tahap selanjutnya yaitu tahap uji coba yang akan dilaksanakan di MAN 1 Model Lubuklinggau. Berikut hasil perhitungan rekapitulasi hasil keseluruhan dari tiga ahli dapat dilihat pada tabel 3.

Tabel 3. Rekaptulasi Validasi Ahli

\begin{tabular}{c|c|c|c}
\hline \multirow{2}{*}{$\begin{array}{c}\text { Peng- } \\
\text { ulangan }\end{array}$} & Materi & Grafis & Kurikulum \\
\hline 1 & 20 & 45 & 48 \\
\hline 2 & 34 & 48 & 51 \\
\hline 3 & 38 & - & - \\
\hline Persentase & $80,2 \%$ & $91,2 \%$ & $95,5 \%$ \\
\hline Kategori & Baik & $\begin{array}{c}\text { Sangat } \\
\text { Baik }\end{array}$ & $\begin{array}{c}\text { Sangat } \\
\text { Baik }\end{array}$ \\
\hline Total & \multicolumn{3}{|c}{$87,90 \%$ (Sangat Baik) } \\
\hline
\end{tabular}

Kelayakan buku ajar fisika berbasis kontekstual secara empiris melalui tahapan uji coba one to one, Small group, dan field test untuk melihat kepraktisan buku ajar yang dilaksanakan di MAN 1 Model Lubuklinggau.

a) Pelaksanaan Uji Coba Perorangan (One To One). Uji coba one to one dilaksanakan pada tanggal 13 Maret 2019, dengan melakukan wawancara kepada tiga orang siswa kelas XI IPA1. Agar tidak mengganggu pelajaran lain uji coba one to one dilakukan di ruangan multimedia pada saat jam pelajaran kosong. Hasil wawancara one to one pada buku ajar berbasis kontekstual; dilakukan pada tiga indikator yaitu: a) desain buku ajar; b) kemudahan pemahaman materi; dan c) keterbacaan isi materi; tersebut. Pelaksanaan uji coba one to one dilakukan guna melihat kepraktisan penggunaan buku ajar berbasis kontekstual.

b) Pelaksanaan Uji Coba Small Group. Uji coba kelompok kecil dilaksanakan pada tanggal 20 Maret 2019 hari Kamis dilaksanakan di perwakilan kelas XI IPA saat jam istirahat, dengan memberikan angket. Peserta terdiri tiga orang siswa berkemampuan tinggi, tiga orang siswa berkemampuan sedang, dan tiga orang berkemampuan rendah dari masing-masing perwakilan kelas XI IPA. Angket ini menggunakan skala likert mempunyai gradasi dari sangat setuju sampai sangat tidak setuju yang dapat dikategorikan sebagai berikut: sangat setuju (SS), setuju (S), tidak setuju (TS), dan sangat tidak setuju (STS).

Hasil persentase respon siswa pada uji coba Small group disajikan dalam bentuk diagram berikut:

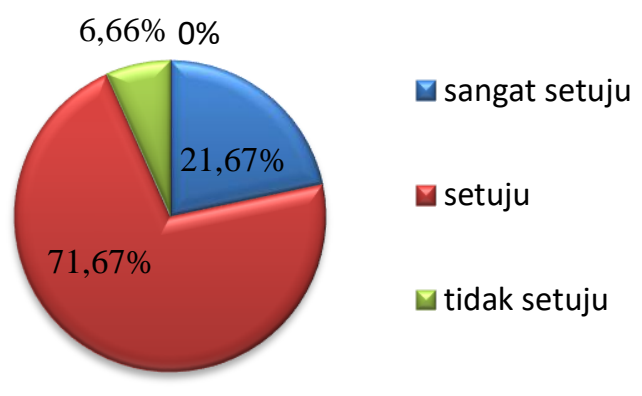

\section{Gambar 1. Diagram Hasil Respon Siswa}

c) Pelaksanaan Uji Coba Field Test. Uji coba field test, dilakukan pada siswa perwakilan kelas XI IPA yang berjumlah 30 siswa di MAN 1 Model Lubuklinggau yang dilaksanakan dari tanggal 5 April 2019 sampai 10 April 2019, tediri atas 12 siswa laki-laki dan 18 siswa perempuan. Pada tahap akhir, uji coba yang dilakukan untuk mendapatkan informasi yang menyeluruh tentang kualitas produk buku ajar berbasis kontekstual, tahap uji coba field test merupakan tahap praktikalitas, yaitu untuk melihat kepraktisan dari buku ajar fisika berbasis kontekstual.

Berdasarkan hasil dari uji coba one to one, Small group, dan field test dapat disimpulkan bahwa buku ajar fisika termodnamika berbasis kontekstual menunjukkan penilaian yang sangat baik. Oleh karena itu, buku ajar fisika berbasis kontekstual dapat dikatakan praktis dan dapat digunakan. Tahapan akhir dari penelitian ini adalah untuk melihat keefektifan buku ajar fisika berbasis kontekstual. Keefektifan tersebut dapat dilihat dari hasil belajar siswa dalam ranah kognitif, afektif, dan psikomotorik serta respon siswa terhadap pembelajaran menggunakan pendekatan kontekstual. Sebelum masuk ke tahap akhir, peneliti melakukan kegiatan praktikum untuk 
menilai hasil belajar siswa dalam ranah afektif atau sikap saat kegiatan praktikum dan dalam ranah psikomotor. Dalam kegiatan praktikum, peneliti melibatkan lima mahasiswa fisika untuk menjadi pengamat/observer dalam menilai siswa. Setelah dinilai oleh obsever didapatkan hasil presentase rata-rata siswa ranah afektif sebesar 85,5\% (sangat baik) dan hasil presentase rata-rata siswa ranah psikomotor sebesar 87,7\% (sangat baik).

Dalam ranah kognitif yang dinilai yaitu nilai tes siswa setelah mengunakan buku ajar fisika berbasis kontekstual. Hal ini dilakukan untuk melihat keefektifan buku ajar berbasis kontekstual materi termodinamika dari hasil belajar siswa. Uji coba hasil belajar dalam ranah kognitif dilakukan untuk mengetahui tingkat kemampuan siswa setelah menggunakan buku ajar berbasis kontekstual. Tes ini dilaksanakan setelah selesainya proses kegiatan belajar mengajar, siswa diberikan waktu selama dua jam pelajaran untuk menyelesaikan soal tes. Berdasarkan kriteria hasil tes ulangan harian siswa dapat dicapai dengan baik atau efektif apabila mendapat nilai akhir $\geq 70$. Setelah diadakan pelaksanaan tes yang mengikuti tes ulangan harian ada 30 siswa. Terdapat 26 siswa yang nilainya di atas skor 70 dapat dinyatakan tuntas, dan 4 siswa yang nilainya kurang dibawah 70 dapat dinyatakan belum tuntas. Dengan demikian buku ajar berbasis kontekstual sudah dapat dikatakan efektif dengan ketuntasan efektivitas pembelajaran secara klasikal sebesar $87,90 \%$.

Respon siswa terhadap pembelajaran dilakukan dengan tujuan untuk melihat keefektifan buku ajar fisika berbasis kontekstual. Untuk mengetahui hal tersebut peneliti memberikan angket tertutup kepada siswa dengan 20 butir pernyataan. Angket ini diberikan setelah seluruh proses pembelajaran selesai. Hasil angket respon siswa secara keseluruhan terhadap pembelajaran dengan pendekatan kontekstual terbilang sangat baik dengan persentase $92,6 \%$ (sangat baik). Hal ini menunjukkan respon yang sangat baik terhadap pembelajaran dengan pendekatan kontekstual siswa kelas XI IPA 1 di MAN 1 Model Lubuklinggau tahun pelajaran 2019/2020. Adapun hasil persentase keefektifan buku ajar disajikan dalam bentuk gambar berikut:

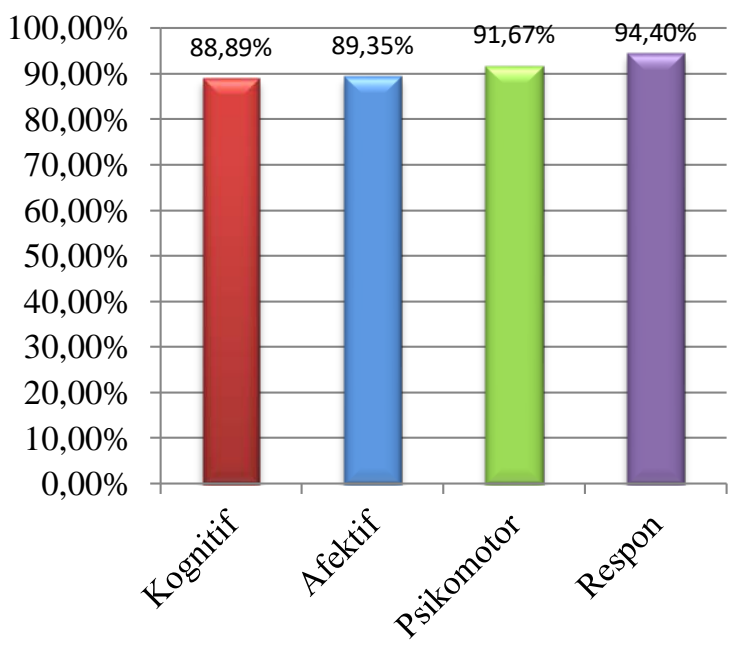

\section{Gambar 2. Persentase Efektivitas Buku Ajar dan Respon Siswa}

\section{Pembahasan}

Berdasarkan analisa kebutuhan pada tahapan pertama yakni mengidentifikasi kesenjangan keadaan dahulu dan keadaan yang sekarang berdasarkan observasi peneliti mendapatkan informasi melalui observasi dan terjun langsung kelapangan di MAN 1 Model Lubuklinggau menunjukkan bahwa siswa masih banyak mengalami misskonsepsi termodinamika, kesalahan dalam mengkonversikan satuan, kesultitan dalam operasi aljabar dan akhirnya termodinamika menjadi materi yang menyulitkan. Kemampuan pengajar harus bisa memberikan apersepsi secara kontekstual dalam kehidupan nyata dalam pemahaman teori termodinamika. Pada saat menyampaikan apersepsi, sejalan dengan penelitian Murtiani. (2012) dan Mukayatun (2013). Selanjutnya keterampilan pengajar harus dituntut untuk kreatif dalam mengaitkan antara konsep teori dengan aplikasinya dalam kehidupan yang nyata sejalan dengan penelitian terdahulu oleh Sujanem, R., (2012) dan Utomo, L. A., dan Muslimin (2015). Apalagi kebutuhan akan hadirnya buku ajar fisika berbasis kontekstual pada materi termodinamika, dapat dilihat pada Tabel 4.

Tabel 4. Kesenjangan dahulu dan sekarang

\begin{tabular}{l|lr}
\hline \multicolumn{1}{c|}{ Dahulu } & \multicolumn{2}{|c}{ Sekarang } \\
\hline Belum adanya buku & Materi Termodinamika \\
ajar fisika berbasis & dikemas lebih menarik \\
kontekstual $\quad$ di & dan memudahkan siswa \\
\hline
\end{tabular}




\begin{tabular}{|c|c|}
\hline Dahulu & Sekarang \\
\hline $\begin{array}{lr}\text { subjek } & \text { penelitian } \\
\text { belum } & \text { menerapkan } \\
\text { tujuh } \quad \text { komponen } \\
\text { penting } \quad \text { dalam } \\
\text { proses } \\
\text { pembelajaran } \\
\text { kontekstual }\end{array}$ & $\begin{array}{l}\text { untuk memahaminya } \\
\text { dengan menghadirkan } \\
\text { aplikasi termodinamika } \\
\text { dalam kehidupan sehari- } \\
\text { hari sehingga sangat } \\
\text { konteksual }\end{array}$ \\
\hline 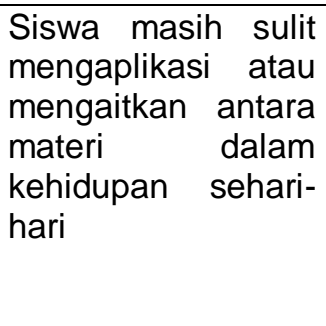 & $\begin{array}{l}\text { Dengan adanya buku } \\
\text { ajar fisika berbasis } \\
\text { kontekstual ini } \\
\text { diharapkan siswa dapat } \\
\text { mengaplikasikan atau } \\
\text { mengaitkan teori } \\
\text { dengan kehidupan yang } \\
\text { nyata }\end{array}$ \\
\hline $\begin{array}{lr}\text { Masih } & \text { kurang } \\
\text { pemahaman } & \text { Siswa } \\
\text { dengan } & \text { materi } \\
\text { khususnnya } & \text { materi } \\
\text { termodinamika. }\end{array}$ & $\begin{array}{l}\text { Dengan adannya buku } \\
\text { ajar fisika berbasis } \\
\text { kontekstual pemahaman } \\
\text { siswa dalam materi } \\
\text { termodinamika } \\
\text { diharapakan memahami } \\
\text { karena terdapat suatu } \\
\text { konsep dan terdapat } \\
\text { penjelasan suatu kaitan } \\
\text { antara materi dengan } \\
\text { kehidupan yang nyata } \\
\text { serta memudahkan } \\
\text { siswa memahami suatu } \\
\text { konsep. }\end{array}$ \\
\hline $\begin{array}{l}\text { Hampir } 87 \% \text { siswa } \\
\text { mengalami } \\
\text { kesalahan hitung, } \\
\text { misskonsepsi } \\
\text { sering terjadi. }\end{array}$ & $\begin{array}{l}\text { Siswa lebih mengerti } \\
\text { dengan memperbanyak } \\
\text { dan mengerjakan soal } \\
\text { soal latihan yang } \\
\text { terdapat di buku. }\end{array}$ \\
\hline Masih monoton & $\begin{array}{l}\text { Buku ajar fisika berbasis } \\
\text { kontekstual ini telah } \\
\text { menerapkan antara teori } \\
\text { dengan kehidupan yang } \\
\text { nyata dimana terletak } \\
\text { pada } \\
\text { konstruktivisme. }\end{array}$ \\
\hline
\end{tabular}

Fayakun, M dan Joko, P., (2015) dan Zulhaini, dkk. (2016) menjabarkan tahapan pengembangan yakni adalah (1) Menulis tujuan instruksional khusus dengan mengembangkannya dari kompetensi dasar yang merupakan tujuan instruksional umum (TIU). Untuk TIK merumuskannya menggunakan format $A B C D$ (Audience, Behavior, Condition, and Degree), yakni Audience merupakan sasaran yang dituju, behavior merupakan kemampuan yang harus dimiliki siswa setelah mengikuti pembelajaran, condition menujukkan kemampuan awal dalam proses penilaian. Selanjutnya degree menunjukkan tingkat subjek penelitian. Setelah kita menyelesaikan tahapan ABCD, sejalan dengan penelitian yang dilakukan Yolanda, Y. (2020) dan Utomo, L. A., \& Muslimin. (2015). Maka kita membuat TIK termodinamika yang sesuai dengan tujuan pembelajaran, Zulhaini, dkk. (2016). Tabel 5. TIU dan TIK Pembelajaran

Tujuan Intruksional umum (TIU)

Tujuan intruksional umum termodinamika terdiri dari pengertian termodinamika, energi panas, kerja, entropi dan kespontanan proses. Tujuan Intruksional Khusus (TIK)

1. Setelah menggunakan buku ajar fisika berbasis kontekstual, diharapkan Siswa mampu menganalisis soal fisika dengan menggunakan prinsip termodinamika 1.

2. Setelah menggunakan buku ajar fisika berbasis kontekstual, diharapkan Siswa mampu menganalisis soal fisika dengan siklus Isobarik (Tekanan Tetap)

3. Setelah menggunakan buku ajar fisika berbasis kontekstual, diharapkan Siswa mampu menganalisis soal fisika dengan siklus Isokhorik.

4. Setelah menggunakan buku ajar fisika berbasis kontekstual, diharapkan Siswa mampu menganalisis soal fisika dengan siklus Isotermis (Suhu Tetap)

5. Siswa mampu membedakan penerapan hukum termodinamika $0,1,2$ dan 3 .

Emzir. (2011) dan Setiawan, Denny, dkk. (2017) mengatakan bahwa pembuatan instrumen, analisa instrumen yang harus digunakan peneliti mencakup instrumen hasil belajar siswa dan angket respon yang dibantu oleh tim observer. Dalam penelitian ini kami membuat dan menyusun strategi pembelajaran yaitu mengembangkan perangkat pembelajaran yaitu rencana pelaksanaan pembelajaran (RPP) untuk mengembangkan materi termodinamika dalam buku ajar ini. Murtiani. (2012); Yolanda, Y. (2020) dan Utomo, L. A., \& Muslimin. (2015) menjabarkan bahwa Tahap mengembangkan buku ajar pada materi termodinamika yang dikembangkan dengan menerapkan tujuh komponen menjadi ciri khas dari model kontekstual dengan melibatkan tujuh kompenen tersebut akan ditampilkan dalam buku ajar tersebut berdasarkan sumber-sumber bahan 
fisika materi termodinamika. Buku ajar fisika berbasis kontekstual pada materi termodinamika yang dikembangkan itu memuat materi, contoh soal dan soal latihan beserta kunci jawaban keseluruhan dari suatu soal yang terdapat di dalam buku ajar tersebut.

Selanjutnya melakukan tahapan revisi dan validasi, setelah buku ajar draf 1 selesai dirancang, selanjutnnya peneliti melakukan Forum Diskusi Grup (FGD) bersama dosen pendidikan fisika ibu Ida Kurnia, M.Pd., Linda Kurniawati, M.Pd. Sutoro, M.Pd. di Sekolah sebagai tempat penelitian dan Dosen Pendidikan Fisika yaitu Ibu Tri Ariani, M.Pd Si. Dan Ibu Wahyu Arini, M.Pd.Si. Tujuan FGD ini adalah melihat isi dari buku ajar dari segi khususnya materi, desain yang diguanakan serta tata bahasa. Pada buku ajar draf 2, melakukam diskusi kembali FGD selanjutnnya peneliti melakukan beberapa hal yang harus diperbaiki sebelum melakukan penelitian.

Kelayakan Buku ajar secara teoritik ini melalui tahapan evaluasi ahli untuk melihat kevalidan buku ajar yang divalidasi oleh ahli materi, desain serta tata bahasa sehingga buku ajar tersebut baik digunakan ke siswa kemudian dalam tahap kelayakan buku ajar ini akan dilaksanakan uji coba one to one, small group serta field test. Kelayakan buku ajar fisika berbasis kontekstual pada kelayakan buku ajar secara teoritik terdiri dari evaluasi ahli materi, desain serta tata bahasa, sejalan dengan pendapat Zulhaini, dkk. (2016); Yolanda, Y. (2020) dan Setiawan, Denny, dkk. (2017).

Adapun sumbangsih terhadap ilmu pengetahuan dalam penelitian ini menjadi alasan peneliti mengembangkan buku ajar yakni dapat memfasilitasi pengajar dalam menyampaikan materi sehingga proses belajar mengajar semakin baik; dapat memfasilitasi siswa untuk belajar mandiri dengan mempelajari dan menumbuhkan minat membaca siswa dengan adanya modul berbasis kontekstual sehinga modul semakin praktis dan menarik. Berdasarkan hasil analisa secara kuantitatif, dapat dijabarkan pengembangan buku ajar fisika termodinamika berbasis kontekstual efektif, sejalan dengan pendapat ahli Zulhaini, dkk. (2016) dan Yolanda, Y. (2020). Setelah diterapkan hasil belajar siswa signifikan tuntas yakni uji hipotesis efektivitas dengan $t_{\text {tabel }}$ dengan $\mathrm{dk}=31-1=30$ dengan $\alpha=$ 0,05 dengan $\alpha \quad(0,05)=1,669$ Jadi $t_{\text {hitung }}>t_{\text {tabel }}$ $3,102>1,669$ maka $H_{a}$ diterima dan $H_{o}$ ditolak. Selanjutnya kelebihan dan kekurangan tentang produk berbasis kontekstual menurut Fayakun, M dan Joko, P., (2015); Utomo, L. A., \& Muslimin. (2015) benar adanya.

\section{SIMPULAN}

Berdasarkan hasil penelitian dengan menggunakan buku ajar termodinamika berbasis kontekstual dapat disimpulkan efektif dan respon siswa dalam penggunaan buku sangat baik.

\section{UCAPAN TERIMA KASIH}

Tidak lupa penulis ucapkan terima kasih sebesar-besarnya kepada Kepala Sekolah dan Dewan Guru MAN 1 Model Lubuklinggau dan Kampus Cemerlang STKIP PGRI Lubuklinggau. Beserta Kementerian Agama Provinsi Sumatera Selatan yang telah memberikan izin kepada kami untuk melaksanakan penelitian di MAN 1 Model Lubuklinggau.

\section{DAFTAR PUSTAKA}

Baroh, Chasniatul. (2010). Efektivitas Metode Simulasi dalam Pembelajaran Matematika pada Pokok Bahasan Peluang di Kelas IX-A MTs Nurul Huda Kalanganyar Sedati Sidoarjo. Skripsi Pendidikan Matematika.

Chaedar. A. (2009). Tujuan Pendidikan Kontekstual. Bandung. Mizan Learning Centre.

Emzir. (2011). Metode Penelitian Kualitatif Analisis Data. Jakarta: raja Grafindo Persada.

Fayakun, M dan Joko, P., (2015). Efektivitas Pembelajaran Fisika Menggunakan Model Kontekstual (CTL) dengan Metode Predict, Observe, Explain Terhadap Kemampuan Berpikir Tingkat Tinggi. Jurnal Pendidikan Fisika Indonesia. 11(1); 49-58. DOI: 10.15294/jpfi.v11i1.4003.

Gay, L.R. dan Geoffrey E. Mills Peter Airasian. (2009). Educational Research: Competencies for Analysis and Applications. Colimbus Ohio. New Jersey.

Gall, Joyce P. Gall \& Walter R. Borg (2010). Educational Research in Introduction. Logman. 
Hosnan, M. (2016). Pendekatan Saintifik dan Kontekstual Dalam Pembelajaran Abad 21. Bogor: Ghalia Indonesia.

Imaduddin, M., Tantayanon, S., Hidayah, F. F., \& Zuhaida, A. (2020). Pre-service science teachers' impressions on the implementation of small-scale chemistry practicum. Thabiea : Journal of Natural Science Teaching Vol. 3(2), pp. 162-174, 2020 Available online at http://journal.iainkudus.ac.id/index.php/Thab iea p-issn: 2580-8474, e-issn: 2655-898X. DOI: http://dx.doi.org/10.21043/thabiea.v3i2. $\underline{8893}$

Johnson, Elaine B. (2009). Contextual Teaching And Learning.Bandung. Mizan Learning Centre.

Murtiani. (2012). Application of Lesson Study Based Contextual Teaching And Learning (CTL) Approaches in Improving the Quality of Physics Learning in Padang City Middle School. Journal of Physics Learning Research, 1 (1); 1-21.

Mukayatun (2013). Biology Learning with CTL Approach with Network Tree Technique and Spider Concept Map Judging from the Students' Creativity and Thinking Style. Journal of Inquiry, 2(1); 14-24.

Nasution. (2012). Kurikulum Pengajaran.Jakarta: PT Bumi Aksara

Setiawan, Denny, dkk. (2017). Pengembangan Buku ajar. Jakarta: Universitas Terbuka

Serway, Raymond A. dan Jhon W. Jewett. (2009). FISIKA untuk Sains dan Teknik. Jakarta: Salemba Teknika.

Sugiyono. (2012). Metode Penelitian Pendidikan: Pendekatan Kuantitatif, Kualitatif, dan $R$ \& $D$. Bandung: Alfabeta.

Sujanem, R., (2012). Pengembangan Modul Fisika Kontekstual Interaktif Berbasis Web Untuk Meningkatkan Pemahaman Konsep dan Hasil Belajar Fisika di Singaraja. Jurnal Nasional Pendidikan Teknik Informatika (JANAPATI). 1(2); 103-117.
Tomlinson, Brian. (2011). Materials Development in Language Teaching Comridge: University Press.

Trianto. (2013). Mendesain Model Pembelajaran Inovatif-Progresif Konsep, Landasan, dan Implementasinya pada Kurikulum Tingkat Satuan Pendidikan (KTSP). Jakarta: Kencana Prenada Media Group.

Utomo, L. A., \& Muslimin. (2015). Pengembangan Bahan Ajar Berbasis Multimedia PembelajaranInteraktif Model Borg And Gall Materi Listrik Dinamis Kelas X SMA Negeri 1 Marawola. Jurnal Pendidikan Fisika Tadulako (JPFT). 4(2);10-16.

Yasa, G. A. A. S., (2012). Pengembangan Bahan Ajar Online Mata Kuliah Micro Teaching dengan Model Borg \& Gall pada Program S1 Pendidikan Bahasa Inggris STKIP Agama Hindu Singaraja. Tesis. Program Studi Teknologi Pembelajaran, Program Pascasarjana Universitas Pendidikan Ganesha, Singaraja. 1-16.

Yanti, Ana Isqa Riski. (2013). Jurnal Analisis Buku Pelajaran Fisika Sekolah Menengah Atas Kelas $X$ yang Banyak Digunakan di SMA Negeri Se-Kabupaten Kebumen. 3 (2), 4-3.

Yolanda, Y. (2020). Development of ContextualBased Teaching Materials in The Course of Magnetic Electricity. Thabiea: Journal of Natural Science Teaching Vol. 3(1), pp. 5969, 2020 Available online at http://journal.iainkudus.ac.id/index.php/Thab iea p-issn: 2580-8474, e-issn: 2655-898X. http://dx.doi.org/10.21043/thabiea.v3i1.66 16

Yolanda, Y. (2018). Profil Keterampilan Proses Sains Fisika siswa SMA di Kota Lubuklinggau pada pokok bahasan Listrik Dinamis. Thabiea: Journal of Natural Science Teaching. Program Studi IImu Pengetahuan Alam IAIN Kudus. 1(2); 70-78. http://dx.doi.org/10.21043/thabiea.v1i2.4067

Yolanda, Y. (2019). Profil Keterampilan Proses Sains (KPS) Mahasiswa Fisika pada Materi Listrik Magnet. JIPFRI (Jurnal Inovasi Pendidikan Fisika Dan Riset IImiah), 3(2), 
70-78.

https://doi.org/10.30599/iipfri.v3i2.533

Yuliyanti, T.E dan A. Rusilowati. (2014). Analisis Buku Ajar Fisika SMA Kelas XI Berdasarkan Muatan Literasi Sains di Kabupaten Tegal. Unnes Physics Education Journal. No. $3 \mathrm{Vol}$ 2, hal 68-72.

Zhang, Y. (2001). Book Review: Fundamentals of Engineering Thermodynamics. In International Journal of Mechanical Engineering Education (Vol. 29, Issue 1). https://doi.org/10.7227/ijmee.29.1.2

Zulhaini, dkk. (2016). Pengembangan Modul Fisika Kontekstual Hukum Newton Untuk Meningkatkan Pemahaman Konsep Fisika Siswa Di MAN Model Banda Aceh. Jurnal Pendidikan Sains Indonesia 04 (02), 180-19 